\title{
APPLICATION OF PROFIT AND LOSS SHARING MODES IN TRADE FINANCING FOR SMALL-SCALE BUSINESSES: AN ALTERNATIVE TO DEBT BASED FINANCING
}

\author{
Muhammad Abdurrahman Sadique*
}

\begin{abstract}
The current article analyses the application of Islamic financing modes based on equity participation for small and medium scale enterprises in short-term trade financing. In lieu of debt based modes such as murabahah favoured by Islamic banks in trade financing, the application of musharakah based alternatives is explored, with especial attention to practical aspects of relevance from a shari'ah perspective arising in their implementation. Financing goods ready for sale, and financing purchase of stock are examined, comparing the joint-equity based structure with the debt-based structures, and identifying issues of importance. The equity based approach being applied as an all-embracing scheme encompassing purchase of raw material or trade goods to their final sale could be a viable and fairer alternative to debt based financing methods in vogue currently. Adopting suitable equity based structures, especially in the context of short-term financing for small-scale businesses, may provide considerable efficiency and convenience without the involvement of the drawbacks inherent to debt financing structures. Eliminating elements of debt financing from the equity-based modes so as to reveal their full potential and to realise their socio-economic objectives requires further study and continuous fine-tuning of the modes proposed.
\end{abstract}

Key words: musharakah, Islamic, equity, short-term, trade, financing, partnership

\footnotetext{
* Associate Professor, Ahmad Ibrahim Kulliyyah of Laws, International Islamic
} University Malaysia, sadique@iium.edu.my 


\title{
PENGGUNAAN MOD PERKONGSIAN KEUNTUNGAN DAN KERUGIAN DALAM PEMBIAYAAN PERNIAGAAN PERNIAGAAN SKALA KECIL: ALTERNATIF KEPADA PEMBIAYAAN BERASASKAN HUTANG
}

\begin{abstract}
ABSTRAK
Makalah ini menganalisa penggunaan mod pembiayaan Islam berdasarkan penyertaan ekuiti untuk perniagaan berskala sederhana dan kecil dalam pembiayaan jangka pendek. Sebagai ganti kepada mod berasaskan hutang seperti murabahah yang digemari oleh bankbank Islam dalam pembiayaan perniagaan, penggunaan alternative berasaskan musyarakah diterokai, dengan perhatian khas kepada aspek-aspek praktikal yang relevan daripada perspektif syariah yang timbul daripada pemakaiannya. Kajian ini merangkumi perincian tentang pembiayaan barangan yang siap untuk dijual serta pembiayaan pembelian stok, membandingkan struktur pembiayaan berasaskan usahasama-ekuiti dengan struktur berasaskan hutang, dan mengenalpasti isu-isu yang penting. Pendekatan berasaskan ekuiti yang digunapakai sebagai skema yang menyeluruh yang merangkumi pembelian bahan mentah atau barangan perdagangan ke penjualan akhir boleh menjadi alternatif yang lebih berdaya maju dan saksama kepada pembiayaaan berasaskan hutang yang sedang popular sekarang ini.

Mengguna pakai struktur berasaskan ekuiti yang sesuai, lebih lagi dalam konteks pembiayaan jangka pendek untuk perniagaan berskala kecil, akan memberikan kecekapan dan kemudahan tanpa pembabitan kelemahan yang wujud dalam struktur pembiayaan berasaskan hutang. Penghapusan unsur-unsur pembiayaan berasaskan hutang daripada mod pembiayaan ekuiti supaya mendedahkan potensi penuh dan mencapai objektif sosio ekonomi memerlukan kajian yang lebih lanjut dan mod-mod yang dicadangkan harus diperhalusi secara berterusan.
\end{abstract}

Kata kunci: musharakah, Islamik, ekuiti, pembiayaan jangka pendek, perdagangan, pembiayaan, perkongsian 


\section{INTRODUCTION}

Equity based financing structures, where funds are provided as capital rather than a loan, could be used with advantage in a number of areas of trade financing. In addition to a more mutually satisfying distribution of gains as well as liability, adopting the equity basis could pave the way to solving many of the difficulties that are experienced currently due to a forced application of murabahah and other debt-based alternatives. ${ }^{1}$ Equity based financing arrangements for commercial enterprises need not be restricted to funding full-scale ventures through provision of initial capital. In order to facilitate a general analysis of the relevant shari ${ }^{6}$ ah and practical aspects, the major areas where equity financing could be applicable in the context of commercial financing can be broadly delineated as financing venture capital, financing trade goods ready for sale, financing stock purchase, and financing working capital. ${ }^{2}$

The current paper focuses on employing joint-equity based formats as a stand-alone mode for short-term trade financing. In what follows, methods of financing sale of produced goods and financing purchase of stock for production or resale on equity basis are explored. Although discussed in the context of small-scale ventures, the principles and practical aspects discussed are of relevance to financing larger ventures as well.

\section{FINANCING SALE OF READY MADE GOODS}

Financing sale of ready made stock refers to financing trade goods that have already come into the possession and ownership of the bank's client $^{3}$ who needs finance. Broadly, this may include goods of diverse types in various situations such as goods produced by manufacturers that are ready for sale or export, buildings and houses constructed awaiting sale or lease, and merchandise purchased that are to be sold or exported. Finance required by the owner could be for paying

\footnotetext{
1 Some details on how murabahah is applied by banks in trade financing can be found further along the paper. An in-depth discussion of some practical and Shari'ah aspects related to the application of murabahah and some other modes of financing is undertaken in the author's forthcoming book "Financing Modes in Islamic Banking."

2 Muhammad Abdurrahman Sadiqque, "Financing Trade Asset Procurement and Disposal on Joint Equity Basis for MMES: An Analysis of Some Vital Shari'ah and Operational Aspects" Journal of Islamic Economics, Banking and Finance, 6 no.1 (2010): 128.

The borrower, in conventional banking terms. Since no loan is extended in the modes of financing discussed here, this term is hardly suitable.
} 
outstanding dues resulting from their procurement, or for replenishing his liquidity after having paid or incurred expenses for the goods, until proceeds are realised through their disposal. From a shari'ah perspective, the distinctive features of importance here could be identified as two. The first is that the bank's client already having title to the assets requiring financing, the stage of procurement has come to an end. ${ }^{4}$ The second feature of importance is that the goods may bring revenue through their sale or lease. When financing projects that have reached this stage takes the form of equity participation, a structure based on musharakah ${ }^{5}$ could appear best suited. This is in view of the fact that the assets are to be disposed of through sale, enabling sharing of proceeds.

\section{ASPECTS OF CONCERN}

In the customary practice of Islamic banks, in addition to equity-based structures, several debt-financing arrangements too are utilised in such instances. These involve various arrangements adapted from factoring mechanisms, which essentially consist of the bank purchasing the ready assets from its client against immediate payment, thereafter appointing him as the agent of the bank for their sale onwards to others, against cash or on deferred payment basis. The net proceeds through the sale after settling costs incurred by the client in carrying out the sales on behalf of the bank would be claimed by the bank. While theoretically, such a structure could be validly conceived, albeit with observance of general conditions applicable to all contracts of sale and agency such as the contracts not being conditional to each other, proper identification

\footnotetext{
$4 \quad$ It should be noted here that if the goods are yet to be paid for, this fact alone would not adversely affect the buyer's ownership and title to the goods in shar 'iah, when the seller had transferred possession of the goods to the buyer and had not retained them until settlement of the price. Having ownership and possession, the buyer may freely transact on the goods. Some schools allow that the goods themselves may be offered as security against the debt, through a separate contract. See Ibn Qudamah al-Maqdisi, al-Sharh al-Kabir 'ala Matn al-Muqni',vol. 4, (Beirut: Dar al-Kitab al-'Arabi, n.d.), 429.

5 Commercial partnership based on jointly invested capital, resulting in joint liability and the right of the partners to manage the venture and share the proceeds. For further details on musharakah and mudarabah as well as diverse shari'ah aspects relevant to equity based financing, Muhammad Abdurrahman Sadiqque, Essentials of Musharakah and Mudarabah (Kuala Lumpur: IIUM Press, 2009); Muhammad Abdurrahman Sadiqque, Capital and Profit Sharing in Islamic Equity Financing (Kuala Lumpur, The Other Press, 2012).
} 
of the subject matter, the prices being definite and mutually agreed etc, ${ }^{6}$ practical implementation poses serious problems pertaining to their shari'ah validity.

Some possible issues of shari'ah relevance that arise in implementation could be enumerated as follows. The bank's purchase of the goods usually takes place only when a confirmed order is available for the consignment, as the profit element for the bank is calculated on the basis of the price receivable from the onward sale and the period of payment. In this event, the bank's purchase being unrelated to the subsequent sale to the ultimate buyer is established only in a theoretical manner. The confirmed order placed by the ultimate buyer sometimes involves elements that dictate the transfer of the goods' ownership to him, occasionally supported by payment of part of the price in advance. Due to the prior agreement in place between the bank and the client, such goods are purchased from the client and sold onward through agency in a routine manner, despite of the fact the ownership of the goods had already passed on to the ordering party. The exchange of offer and acceptance is subject to delays, which may even take place after the goods had been dispatched to the final buyer. The separation and identification of the consignment purchased by the bank are prone to errors, especially when different lots of a single order are financed individually. Subsequent to the purchase of the bank, taking possession of the consignment often fails to materialise, mostly due to insufficient attention paid to this aspect. Apart from the purported understanding between the bank and the client that consignments purchased by the bank would become the bank's property, to be handled by the client thereafter only in the capacity of an agent for sale, such demarcation of different capacities is not considered important by clients. Thus, ensuring the bank's liability of the goods proves unfeasible in practice. All in all, apart from some documentary and pricing aspects, implementation of practical details of relevance pertaining to the occurrence of two distinct contracts of sale hardly materialises in an acceptable manner. Obviously, employment of such debt-based arrangements could only be acceptable when shortcomings similar to the above are avoided. Therefore, such structures may be adopted only in marketing distinct assets such as houses and buildings, as substitutes for murabahah where needed, with the observance of necessary guidelines.

\footnotetext{
Details of the contracts of sale and agency and the conditions necessary to be fulfilled therein can be found in the relevant chapters in the major works of Islamic Law.
} 


\section{ADOPTING JOINT CAPITAL BASIS FOR FINANCING}

If financing ready stock is to be done on equity basis, this could be conveniently carried out based on musharakah, as is in vogue mainly in exports against letters of credit. ${ }^{7}$ This practice may be adopted in other instances involving ready stock as well. Here, a specific musharakah transactional agreement is drawn on the particular consignment of assets, where the financier is introduced as a joint owner of the asset as well as a joint investor, who enters into a partnership with the original owner for the sale of the asset and jointly sharing the proceeds. In case a general agreement for entering into such transactions is already in place, the specific musharakah for the particular consignment could be finalised through reference to the underlying agreement, and specifying the consignment and the proportion of equity participation. When a musharakah is finalised on a particular asset, the parties become coowners of the asset, as a proportionate share in the ownership of the asset passes on to the newcomer, against proportionate share in the cost of the asset. As far as the financier becoming a joint owner in the asset is concerned, Hanafi, Maliki and Shaf'i jurists have considered the transfer of ownership here similar to that in tawliyah, i.e. sale at cost price ${ }^{8}$ while Hanbali jurists describe it as the sale of a part of the asset. ${ }^{9}$ Thus, the establishment of joint ownership of the newcomer over the consignment represents the purchase of a proportionate share of the asset at cost price. Therefore, it is necessary that the initial owner of the asset have it in possession at the time of finalising the musharakah agreement. ${ }^{10}$ When this procedure is adopted by Islamic

\footnotetext{
$7 \quad$ For details of such financing, see the chapter on musharakah financing Muhammad Taqi Usmāni, An Introduction to Islamic Finance, (Karachi: Idaratul Ma'arif, 2000).

'Ala al-Din al-Kasani, Bada 'i ' al-Sana' $i$ ',vol. 5, (Beirut: Dar al-Ma'rifah, 2000), 226; Saḥnun ibn Sa'id, Al-Mudawwanah al-Kubra, vol. 9, (Beirut: Dar Sadir, n.d), 80; Abu Hamid al-Ghazali, al-Wasit, vol. 3, (Cairo: Dar al-Salam,n.d) ,161; Zakariyya ibn Muhammad al-Ansari, Fath al-Wahhab, vol. 1, (Beirut: Dar al-Kutub al-'Ilmiyyah, $1418 \mathrm{H}), 305$.

ManÎr ibn Yunus al-Bahuti, Kashshaf al-Qina',vol. 3, (Beirut: Dar al-Fikr, $1402 \mathrm{H}), 229$.

10 'Ali ibn Sulayman al-Mardawi, al-Inșaf, vol. 4, (Beirut: Dar Ihya al-Turath al'Arabi), 438; Ibn Qudamah, al-Mughni, vol. 4, 95, Zayn ibn Ibrahim ibn Muhammad, Ibn Bakr, al-Bahr al-Ra'iq, vol. 1, (Beirut: Dar al-Ma'rifah), 181; Sahnun ibn Sa'id, al-Mudawwanah al-Kubra, vol. 9, 80; Ahmad ibn 'Ali ibn Hajar al-'Asqalani, Fath alBari Sharh Sahih al-Bukhari, vol. 5, (Beirut: Dar al-Ma'rifah, 1379H), 136. Imam Malik requires that if the initial owner had purchased the asset on credit, the newcomer be required to submit his share of the cost based on identical credit terms. However, if the musharakah arrangement specifically refers to the newcomer paying his share of the cost immediately, it is acceptable, as in this case it would be a sale on different terms.
} 
banks for financing ready stock, the bank becomes a co-owner in the asset according to the proportion specified for equity participation, and the bank may thereafter disburse to the client a proportionate share of the cost incurred by the latter in acquiring the asset.

It is evident that through this procedure, the bank would become owner in only a part of the asset, as the initial owner retaining a proportion of the ownership is necessary for the formation of a valid musharakah relationship. Thus, financing for the complete cost of the asset does not appear feasible under this structure. However, it is understandable that even if the client retains a minimum share of the ownership, it is sufficient to create the musharakah. Such joint partnership may also prove convenient in later operations. For finalising the musharakah arrangement, ensuring possession of the bank's share in an acceptable manner could be necessary as in the case of other purchases. After concluding the musharakah agreement thus, the client becomes empowered to dispose of the asset through sale etc. according to the nature of the venture, without the need for a separate agency. The mutual agency awarded by the musharakah agreement itself is sufficient for both parties to take part actively in disposing of the assets in a profitable manner. Thus, the bank may contribute its expertise in locating potential customers, marketing, advertising, providing financial management etc, as dictated by the nature of the asset. This could be of especial significance to small-sized business clients, as the bank presumably having superior access to market information as well as management and marketing skills, its taking an active role in the micro/medium sized venture could provide a huge boost to the latter.

\section{ISSUES IN ADOPTING THE JOINT CAPITAL BASIS}

The client providing accurate information regarding the cost becomes important here, as the amount financed by the bank depends on the cost revealed by the client. If an amount exceeding the actual cost is given, the client may claim a higher amount of profit than his due, if the profit sharing basis is the same as that of capital. Thus, when there is a doubt regarding the actual cost, the bank may become co-owner in the asset through purchasing the proportion wished to be owned at a price mutually fixed by the parties. Clear agreement of the proportion of capital contribution is necessary also for amicable sharing of any unexpected loss. 
Due to the prevailing practice even in Islamic banking of calculating the bank's profit share based on the capital outlay of the bank and the period taken for realisation of profits, some Islamic banks attempt to adjust the equity format in order to achieve a similar end. ${ }^{11}$ The proportion of the bank's profit share is thus calculated based on the period taken for receipt of payment from the ultimate buyer. As often happens in the case of financing such ventures, the facility is approved only against a confirmed order, possibly supported by a letter of credit issued by the bank of the potential buyer. Thus, the profit division ratio as a rule happens to be different from that of capital participation.

When the profit sharing ratio is determined on this basis, if realisation of profits through the venture delays due to some reason such as delay in payment by the onward buyers, the bank may attempt to alter the ratio already finalised to compensate for such delay, through an increase of its profit share. ${ }^{12}$ To address such eventualities, some mushärakah agreements could involve a clause to the effect that the parties may alter the profit sharing ratio with mutual agreement. ${ }^{13}$ However, it is clear that such altering merely in view of the financial interests of one party seriously affects the consistency of equity relationships, which requires equitable sharing of gains as well as setbacks. In addition to lowering the relationship to a level close to that of lender-borrower, such alterations may lead to creating lack of faith in equity arrangements, as even frequent changes could be justified on this basis, thus paving the way to one party securing a fixed return. In the case of financing micro and medium sized enterprises, this could prove especially negative, as it results in the flexibility of the equity arrangement becoming limited to little more than a theoretical possibility.

In financing sale of produce on equity basis, after finalising the musharakah agreement, in the course of disposing of the asset,

11 For a discussion on how Islamic banks determine the profit sharing ratio, Muhammad Abdurrahman Sadiqque "Profit and Loss Allocation among Islamic Bank and Client Partner in Equity Financing: Practice, Precepts and Alternatives", Journal of King Abdul Aziz University on Islamic Economics, 22, no. 1, (2009).

12 For an analysis of measures adopted by Islamic banks to adjust the profit sharing ratio, Muhammad Abdurrahman Sadiqque, "Measures Affecting the Agreed Profit Sharing Ratio in Joint Ventures Financed by Islamic Banks: a Shari'ah Based Evaluation", (presented at The International Conference on Islamic Economics and Economies of the OIC Countries, Hotel Istana, Kuala Lumpur, 28-29 April 2009).

13 The validity of such clauses in Shari'ah and their implication in the context of modern Islamic banking practice are analysed in Muhammad Abdurrahman Sadiqque, Capital and Profit Sharing in Islamic Equity Financing (Kuala Lumpur: The Other Press, 2012). 
additional costs are sometimes incurred. These may be in the form of advertising, marketing, packing, carriage, shipping, etc. When the initial capital comprises of stock only and adequate monetary capital had not been made available for expenses, the nature of such additional expenses may pose a problem. Usually, these are treated as capital infusion, and the profit share of the bank is reviewed at the end, to compensate the bank. This raises the issue of the capital not being in existence in full at the outset of the venture.

Similarly, in a situation where such expenses are undertaken by the partners disproportionately, if they are identified as additional capital injected by the partners to the venture, it may lead to disruption of the existent proportion of the partners' ownership. If the capital contribution ratio itself is subject to fluctuation during the course of operations in this manner, finalising the musharakah agreement would need to be put off until all costs are known. Therefore, if infusion of fresh capital is needed, this may be achieved through a manner that does not expose the existent capital participation levels to fluctuation. The preferable method to accommodate such expenses would be through the partners making available their proportionate share of the envisaged expenditure at the inception itself or prior to disposal of assets.

However, when a partner undertakes such costs with the approval of the other on behalf of the venture mutually owned by them, these could also reasonably be treated as debts incurred by the venture for which the partners are jointly liable, and therefore have to be settled by both parties. The mere fact that a partner had undertaken the expenses out of his personal funds, the venture thus becoming indebted to a partner instead of a third party, would not necessitate treating the instance as an infusion of fresh capital. Thus, such debts incurred towards expenses would merely represent liabilities undertaken by the venture that have to be settled jointly by the partners.

\section{FINANCING PURCHASE OF STOCK}

An instance where Islamic banks extend funds on equity participation basis pertains to obtaining stock for disposal. The client may seek funds for purchasing stocks of a specific nature, that are required for meeting an order that has already been placed or for fulfilling a current demand in the market. Thus, financing sought here would include the phase of obtaining stock as well as that of disposal and realising the proceeds. In financing micro or medium sized enterprises, as in the case of financing other larger ventures, this category may embrace a 
vast variety of situations involving various means of procurement and disposal. Acquiring stock could take place through import, purchase, manufacture, construction etc., and may even involve more than one of the above, such as when raw material or components are imported or purchased for processing or manufacture of the required item prior to sale. Similarly, disposal of the assets may take diverse forms such as sale, export and lease. It is clear that due to the breadth of this category, it may overlap some areas involving long-term projects, i.e. financing venture capital. The scope of the current discussion is limited to financing purchase of specific assets that require minimum processing, for sale in a ready market.

Debt based arrangements currently in vogue in Islamic banks for financing such enterprises may comprise of two different facilities granted separately towards each phase of the project. Thus, purchase of the necessary stock may be carried out through a murabahah facility for local purchase or import, while the subsequent sale, as described above, could take the form of another murabahah arrangement for local sale or export based on the factoring mechanism, or even financed through an equity based facility. Consequently, the process may entail the bank earning a return in both the stages, usually based on the volume of the facilities as well as the durations taken for settlement in both instances. The nature of the second phase, both when financing is done through a debt based arrangement as well as where an equity basis is adopted, was discussed under the previous category, i.e. financing the sale of readymade goods. We may briefly analyse debt based arrangements employed in financing the first phase, i.e. acquiring stock, and thereafter discuss their equity based counterpart, which would embrace both phases.

\section{DEBT-BASED STRUCTURES FOR PURCHASE OF STOCK}

The primary means employed by Islamic banks for facilitating purchase of stock is the mechanism known as murabahah, or more accurately, bay 'al-murabahah li al-ämir bi al-shirā' (sale on murabahah to the purchase orderer, i.e. sale of an asset on cost-plus-mark-up basis to the party that had advised the seller to purchase it initially). It is widely used in financing asset purchases of all types for consumption, utility or trading, in the local market or through import. Some perceived advantages in this format are: entitlement of the bank to a fixed amount of profit based on its cash outlay and the period required for settlement, asset risk being limited to the minimum duration the asset 
lies in the constructive possession of the bank, resemblance in outcome to conventional banking facilities, and credit risk being covered by a pledge or mortgage. Several bodies of contemporary shari'ah scholars have ruled it permissible in facilitating asset purchase, subject to observing the necessary conditions. ${ }^{14}$ The Islamic Fiqh Academy Jeddah has permitted sales on murabahah to the commissioner-topurchase with regard to goods already in the physical possession of the seller as required by shari'ah, provided the seller carries the risk of loss before delivery, the consequences of returning the purchased goods because of concealed defects, etc., and provided the conditions of the sale are met, with the absence of any impediments. ${ }^{15}$

In murabahah financing as practised by Islamic banks, instead of extending a loan facility to the client for purchasing the required commodity himself, the Islamic bank is required to purchase the commodity from the supplier first. After taking possession of the commodity, the bank sells it to the client usually on deferred payment basis, at a fixed price comprising the procurement cost incurred by the bank and an additional margin of profit. Being limited to an appraisal of equity financing modes, this research does not purport to discuss or analyse issues pertaining to murabahah in detail. However, some vital aspects relevant to financing purchase of stock through murabahah are surveyed below with minimum detail, to appreciate the alternative equity based mechanism.

\section{ASPECTS OF CONCERN IN THE USE OF MURABAHAH}

In financing procurement of trade goods on debt based formats, after the asset required is purchased based on murabahah from the local market or through import, if the client so wishes, the disposal could be facilitated through a factoring mechanism adapted from murabahah, as mentioned above. However, this procedure is prone to error and abuse in both phases in many ways, which makes its proper implementation challenging. In employing murabahah in the first phase, due to the involvement of agency enabling the client to purchase the goods on behalf of the bank and take possession himself, the mechanism becomes

\footnotetext{
$14 \quad$ First Islamic Banking Conference Dubai, 22-24 May 1979, held at Dubai Islamic Bank, in Dubai Islamic Bank, al-Fatawa al-Shari'iyyah fi al-A'mal al-Masrafiyyah, vol. 1, 19; First Albaraka Seminar held in Madinah, June 1983, Resolution No. 8, in Dallah Albaraka, Fatawa: Shariah Rulings on Economics, 103.

15 Islamic Fiqh Academy, Resolution No. 40, 41, (2/5 \& 3/5), $5^{\text {th }}$ Session held in Kuwait in December 1988.
} 
vulnerable to abuse. Although such agency could be theoretically upheld as valid and may facilitate the bank's purchase especially when it may not purchase directly from the supplier for some reason, due to this element, the distinction between the two ownerships, i.e. the initial ownership of bank and that of the client afterwards, becomes marginal, as the transfer from one to the other takes place while the goods are in the custody of the client. The agency also enables exploiting murabahah for obtaining funds, without the involvement of an asset. If funds are released to the client under agency even in a genuine transaction, the client could delay forwarding them, by negotiating credit terms with the supplier. The asset sought to be financed may have already been purchased by the client and taken possession before the involvement of the bank. Ensuring possession of the bank prior to selling the stock to the supplier presents difficulties. The client may even dispose of the goods before purchasing them from the bank, whereas doing so is lawful only after he purchases from the bank through an independent second contract. ${ }^{16}$

\section{FINANCING BASED ON JOINT PARTNERSHIP}

It was mentioned that purchase of stock and their ultimate sale, when bank involvement is sought for both, are financed through two distinct processes not necessarily related to each other, which are usually murabahah based. When such goods are known to be procured for meeting an order placed by another party or for fulfilling a specific demand in the market that is reasonably assured, employing an equity based structure could comprise both the above phases while significantly avoiding many of the vulnerable areas such as mentioned above. Instead of two facilities for each phase, the bank may enter into a musharakah with the client for procuring the asset needed and its disposal. The total capital outlay required for the project could be reasonably assessed, and the bank may invest a part of it as agreed with the client. After finalising the agreement, if purchase is to be carried out locally, the client may commence the process without the need for any agency from the bank, as the musharakah structure empowers him to undertake all activities necessary for the venture. Similarly, the bank too could discharge specialised duties necessary towards the venture,

\footnotetext{
16 Client's purchase of the goods in his custody from the bank cannot be understood to take place automatically through a ta 'ä̈i contract, i.e. an implicit contract clearly indicated by the actions of the contractors, even in the absence of textual expression. Also, an agent for sale may not sell to himself assets belonging to the principal.
} 
in the form of handling financial matters, processing documents, consultancy, providing storage etc. As indicated previously under financing sale of readymade goods, such an active contribution towards the joint venture on the part of the bank would be especially helpful for micro/medium clients, while providing the bank with a chance to better control and monitor the joint venture. If the goods are to be imported, the bank may undertake duties related to the import procedure, while the client may take charge of clearance, processing and preparation for local sale or export. The export procedure could again be handled by the bank on behalf of the partnership. The proceeds, when realised, would be divided between the bank and the client in the agreed proportion after reclaiming the capital and other costs. Any loss would be shared according to the ratio of capital participation.

Carrying out the second phase, i.e. the sale of readymade goods under an equity arrangement, was discussed above. In the current structure, in addition to sale of the assets, the first phase consisting of acquiring the stock too is brought under the equity arrangement. The major difference between the two structures is that, while in the former, the initial capital consisted of undivided shares in the available stock with the possible inclusion of an amount of cash, in the current structure, the initial capital would consist of cash only. This is because the stock needed is yet to be acquired. Thus, after determining the amount of capital necessary as well as the ratio of participation, the partners could make the capital available at the time of commencement of operations, through remittance of funds to the supplier or otherwise. It was shown above that the respective capitals could remain with the partners according to Hanafi jurists, as partnership only materialises in the assets procured for the venture and the profits realised. ${ }^{17}$ The profit sharing ratio, if decided to be other than that of capital participation, may be agreed, also taking into consideration the respective functions undertaken by the partners towards the venture. ${ }^{18}$ However, in the current banking practice, determination of the profit distribution ratio takes place based on the return the bank expects to realise through the venture, which is calculated based on the amount spent by the bank and the period taken for its recovery.

\section{OBSERVATIONS ON THE EQUITY ARRANGEMENT}

Due to transactional powers granted to a partner, many restrictions

\footnotetext{
$17 \quad$ Al-Sarkhasi, al-Mabsü, vol. 11, 152.

18 Ala al-Din al-Kasani, Bada' $i$ ' al-Sana' $i$ ', vol. 6, 100.
} 
placed on him as the bank's agent to purchase would be removed. Difficulties posed due to various stages involved in murabahah that should be strictly observed for its validity are absent under the equity structure. The different capacities borne by the client as an agent holding the goods in custody and thereafter as an owner, the need for timely exchange of offer and acceptance, restrictions on handling the asset until the purchase from the bank is finalised etc. are not found in the equity arrangement. Instead of bearing the risk and liability alone, throughout the tenure, the client shares the burden of any negative outcome with the bank in proportion to capital participation until the proceeds are realised. Presumably being the major partner in the venture injecting the larger share of capital, most of the risk would be borne by the bank.

In adopting the equity structure as a comprehensive scheme for financing micro and medium sized enterprises embracing all stages from acquiring stock until its disposal, many of the controversial aspects affecting the debt based arrangements are avoided. Issues such as the legal enforceability of the promise to purchase, credit price differing from the cash price, the possibility of imposing penalty due to delay in settlement, etc. do not arise under this arrangement. Since the item initially procured itself is to be disposed of, abuse of murabahah for obtaining funds for other purposes may not occur. Similarly, steps such as appointing the client as agent to purchase on behalf of the bank and the sale to the client on murabahah terms are not needed here, as the initial purchase of the asset from the supplier is for the joint venture, through which the proportionate ownership of the bank in the asset is established. Concerns related to import based on murabahah too could be significantly eliminated through the equity structure. Acquiring sole ownership over the imported commodity in the name of the bank is not required in the equity structure, as it is purchased jointly by the bank and the client. Thus, uncertainty about the full-fledged ownership of the bank becomes irrelevant. Similarly, issues pertaining to ascertaining the precise cost are not applicable, due to the absence of a sale on murabahah terms. 


\section{CONCLUSION}

Joint-equity based structures could be adopted with advantage for financing micro and medium sized enterprises in a variety of situations. Being expressly designed for financing, these could replace in many instances debt based modes that have been tailored to fit in artificially. Equity based structures for purchase of stock and sale of readymade goods, especially when used in an micro and medium sized financing context, in addition to being distinctly advantageous through facilitating an equitable sharing of profit and loss, could significantly smoothen the process while avoiding negative aspects related to debt financing mechanisms. However, its application should be done in a way reflective of the reality of the equity partnership, which could lead to realising its full potential. Implementation of the equity relationship requires wholehearted participation by the bank in the operation of the venture in all possible means. In addition to financing ventures, the Islamic bank itself may play an active role in initiating diverse projects, and accumulate expertise and skill necessary for the purpose. 
